\title{
Artistic
}

\section{BIRTH AS A SOURCE OF IDEAS FOR THE CREATION OF TEXTILE ARTWORK}

\author{
Shofia Ajiba Al-Haqiqi \\ Sebelas Maret University, Surakarta, Indonesia \\ E-mail : shiofiaajiba@student.uns.ac.id
}

\begin{abstract}
The design is intended to create new work that focus on textile artwork to convey messages related to birth by exploring visual, symbol, and processing colors and techniques. The purpose of this artwork is to convey messages related to anti-drug awareness through textile artwork for an aesthetic element of the interior. The method used in this creation is the Gustami approach. This method goes through 6 stages, namely finding references in order to explore themes and topics, searching for theoretical foundations to determine techniques, materials, problems in creation, sketching, sketch completion, embodiment, and evaluation. The results of this design showed that (1) exploration in creating interior aesthetic artwork with the source of the idea of "birth" can be done by searching for layered data which is then outlined in a sketch taking into account colors and symbols, and (2) the work is realized with embroidery can be used to convey messages to raise anti-drug awareness in young generations.
\end{abstract}

Keywords: Textiles, rebirth, anti-drugs, creation, and embroidery.

\begin{abstract}
ABSTRAK
Perancangan ini dimaksudkan untuk menciptakan karya baru yang fokus pada seni tekstil untuk menyampaikan pesan terkait kelahiran dengan mengeksplorasi visual, simbol, warna, dan teknik. Tujuan penciptaan karya ini adalah menyampaikan pesan terkait penyadaran anti-narkoba melalui karya seni tekstil untuk elemen estetis interior. Metode yang dipakai yaitu pendekatan Gustami. Metode ini melewati 6 tahap yakni pencarian referensi guna mendalami tema dan topik, pencarian landasan teori guna menentukan teknik, material, masalah pada penciptaan, sketsa, penyempurnaan, perwujudan, dan evaluasi. Hasil perancangan ini menunjukkan : (1) eksplorasi dalam menciptakan karya seni estetis interior dengan sumber ide "kelahiran" dapat dilakukan dengan pencarian data berlapis yang kemudian dituangkan dalam sketsa dengan mempertimbangkan warna dan simbol, dan (2) Karya diwujudkan dengan teknik sulam dapat menyampaikan pesan untuk menggugah kesadaran antinarkoba kepada generasi muda
\end{abstract}

Kata kunci: Tekstil, kelahiran kembali, anti narkoba, penciptaan, dan sulam. 


\section{Introduction}

Entering the $21^{\text {st }}$ century, the art of textile craft has developed quite rapidly. Various long steps have been taken by textile arts activists to expand the world of textiles, for example in interior artworks, various innovations have been born, one of which is the embroidery technique. The creation of this textile art uses embroidery as a technique to embody works with the source of the idea of birth. The birth in this study is the birth of someone from the world of drugs.

The drug problem in Indonesia is still urgent and complex. In the last decade this problem has been increasing. This concern is further strengthened due to the increasing illicit trafficking of narcotics that has spread to all levels of society, including among the young generation. The unstable nature of adolescents requires good direction and care from outsiders to motivate their lives (Prastiwi \& Listyaningsih, 2017).

Article 54 of Law Number 35 of 2009 concerning Narcotics (Undang-Undang Nomor 35 Tahun 2009 tentang Narkotika) states that narcotics addicts and victims of narcotics abusers are obliged to undergo medical rehabilitation and social rehabilitation. Rehabilitation of narcotics addicts is a process of treatment to free addicts from dependence, and the period of undergoing rehabilitation is calculated as a period of doing punishment and learning. Rehabilitation of narcotics addicts is also a form of social protection that integrates narcotics addicts into a social order, so that they no longer commit narcotics abuse.

Based on the phenomenon of drugs and rebirth above, the author is interested in making it as the theme of textile artwork. The creation of this work can be a means of conveying a message, especially for teenagers, not to stop the process to be better. Because adolescents are supposed to play a role as state assets which will become the successor in the future. They deserve to be given knowledge as provision and motivation to live for the best life in the future.

The creation of this work is important because of the positive message contained in a textile artwork. The positive message is that you should not get tired to continue to the process of getting better. The creation of this work is also an 


\section{Artistic}

innovative work as well as a differentiator for previous works. Drug-themed textile works which are realized using embroidery techniques are new and have never existed before. It is hoped that the embroidery technique will be able to give birth to an aesthetic function through every detail and texture that arises from the thread.

\section{Literature Review}

The report of the Unite Nation Office on Drug and Crime in 2018 said that $5.6 \%$ of the world's population had used illegal drugs and 27 million people were still addicted to drugs in the world and 3.6 million of them were drug users in Indonesia in the age range 15-65 years. Most of them are marijuana drug users and most of those drug users are in their teens (Alfiyattur Rohmah, 2016). A survey from the National Narcotics Agency ( BNN ) and the Indonesian Institute of Sciences ( LIPI ) shows that 2.3 million students in Indonesia have ever consumed narcotics. Narcotics addicts are self-victimizing victims, because narcotics addicts suffer from addiction syndrome as a result of the abuse of narcotics that they do themselves.

The government and private institutions in Indonesia have built various protection agencies for drug abusers. Many narcotics abusers have gone through the rehabilitation phase and then feel aware of their mistakes and want to get back on the right life better. They can blend back into their family environment and sometimes even behave better than before. The rehabilitation stage that is passed by narcotics abusers seems to bring the perpetrators to a better level of awareness. Those who

have succeeded in being free from the world of drugs are one example of a person's rebirth from the dark world.

"Rebirth" is known in Hinduism and Buddhism as reincarnation. Besides, Christianity also recognizes the term rebirth. In the Big Indonesian Dictionary (Kamus Besar Bahasa Indonesia), rebirth means the occult process of rebirth in the form of a new creature's body after the old one has died (this is a belief in several religions, such as Hinduism and Buddhism) (https://kbbi.web.id/ born). Rebirth is a circle of life. In order to achieve rebirth, man will be detached from his attachments, for this he must destroy and eliminate his desires. 


\section{Creation Methodology}

The method of creation used in the creation of this work is Gustami's method of creating craft art. Gustami's method of creation consists of three stages and six steps of creating the craft art. The first is the exploration stage which includes observation and searching for literature sources. Second, the design stage is making some sketches and making technical drawings. The third stage, embodiment, is the process of forming and continuing to the assessment and evaluation of the work that has been completed (Gustami, 2001).

Exploration includes steps of soul wandering and exploration in digging the source of ideas. These steps include extracting the source of creation both directly in the field and collecting references data on writings and images related to the design of the work.

The design stage consists of pouring out ideas from the results of the analysis that have been carried out into two-dimensional or design forms. The design results are then manifested in the form of works. The design includes several stages, including an alternative design (sketch). From the several sketches, then the best sketch is selected to be used as the chosen design.

The embodiment stage is the stage of realizing ideas, concepts, foundations, and designs into works. From all the stages and steps that have been taken, it is necessary to evaluate thoroughly to find out the suitability of the idea and the work created. The three stages of Gustami's method of creation above can then be broken down into a six-step of art creation process. The six steps are:

a) Wandering of the soul, namely the field of observation step, extracting reference sources and information to find themes or various problems that require solutions.

b) Exploring the theoretical basis, sources and references as well as visual references. This effort is to obtain material data, tools, techniques, aesthetic elements, aspects of philosophy and social functions as well as an estimate of the advantages of the solving problems offered. 


\section{Artistic}

c) The design for realizing ideas or thoughts from the verbal description from the analysis results into a visual form and a two-dimensional design in the form of a sketch. Things to be considered in this stage include aspects of material, technique, process, method, construction, comfort, harmony, balance, form, aesthetic elements, style, philosophy, message / meaning, economic value, and future market opportunities (for products).

d) Refining the design by realizing the selected design into a design model. The design model is built based on the technical drawings that have been prepared.

e) Visualizing the design into real works until to the finishing and packaging.

Evaluating the results of the embodiment. This can be done in the form of an exhibition or asking for a response from the public in the hope that there will be criticism of the work. Especially for functional works, if various considerations and criteria have been met, the work is ready to be produced. Except with craft work as an expression.

\section{Discussion}

\subsection{Creative Process}

This creation originated from the idea of rebirth as a message for all societies to continue to fight against failure. The birth that is meant here is the success of a person to get out of the dark world that makes that person being a better one. Everyone who has gone through a dark period has the right to live again like people in general.

The concept of the work above is manifested in several stages. The first step is exploration which includes observation and searching for literature sources. 
Table 1. Explore the shape of the mushroom

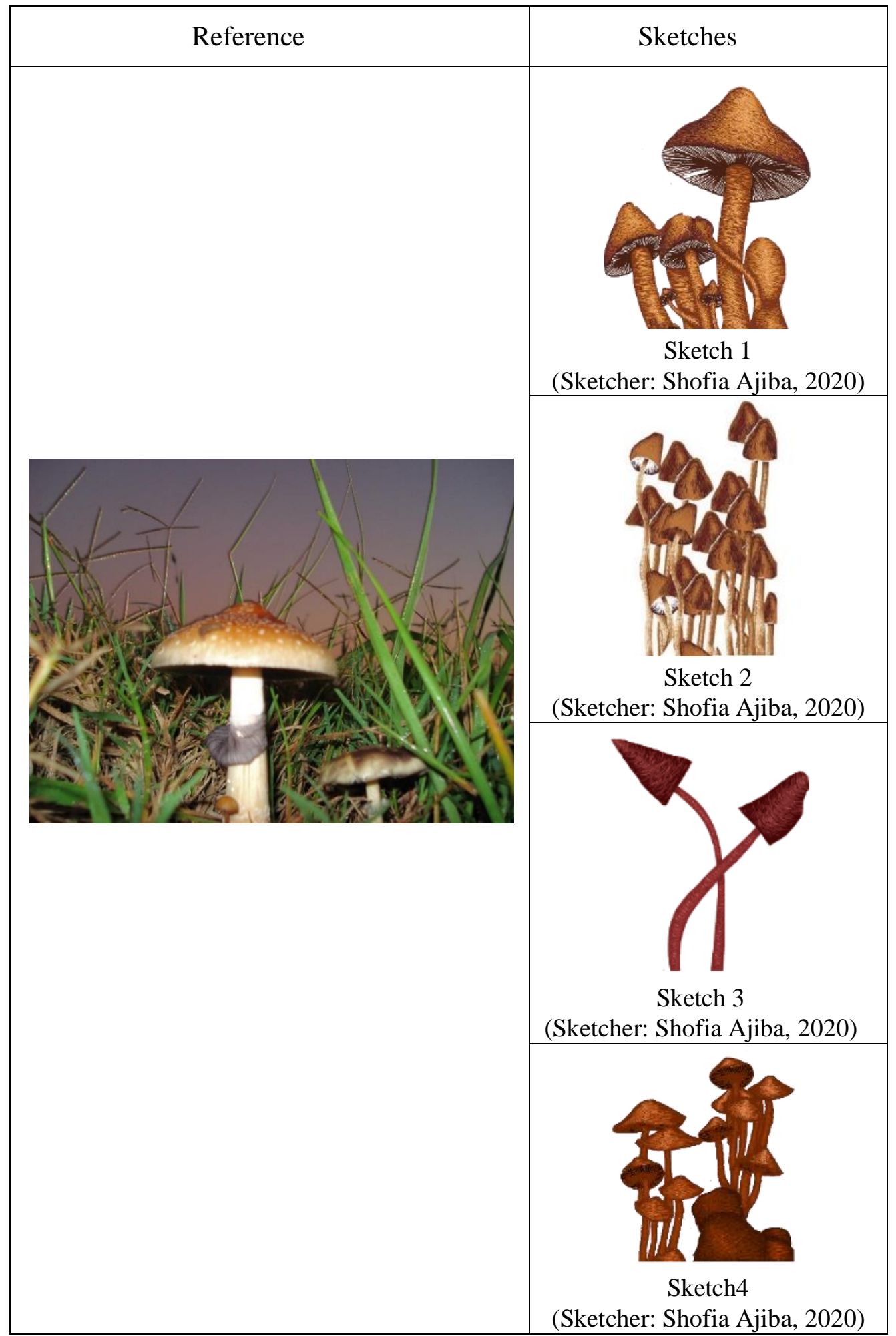




\section{Artistic}

Second, the design stage is making some sketches and making technical drawings.

Table 2. Sketches and description

\begin{tabular}{|l|l|}
\hline No. & \multicolumn{1}{|c|}{ Description } \\
\hline 1 & $\begin{array}{l}\text { Sketch } 1 \text { is defined as a child falling } \\
\text { into the water. He was previously in a } \\
\text { negative world which is interpreted by } \\
\text { black colors and fungi that creep up. } \\
\text { Mushrooms, which are defined as } \\
\text { drugs, are drawn at the top to show } \\
\text { that the drug has previously been } \\
\text { above (overpowered) the child's visual, } \\
\text { then he is able to escape and fall into } \\
\text { the water which is interpreted as a } \\
\text { cleaner. The blue color of the water is } \\
\text { interpreted as a place that can clean } \\
\text { him with various aids such as the } \\
\text { jellyfish colored lavender and plum. } \\
\text { The two colors are intended as a } \\
\text { variety of assistance provided by the } \\
\text { government to release drug users from } \\
\text { drugs. The brown and terra cotta } \\
\text { colors on the mushrooms and the } \\
\text { child's body are interpreted as negative } \\
\text { effects in the form of high self- } \\
\text { confidence, excessive comfort, the } \\
\text { addiction that a person feels when } \\
\text { consuming drugs. The white color that } \\
\text { slowly emerges from the child's feet } \\
\text { means a positive thing that slowly } \\
\text { emerges after the child decides to } \\
\text { undergo a change. }\end{array}$ \\
\hline
\end{tabular}




\begin{tabular}{|c|c|c|}
\hline 2. & 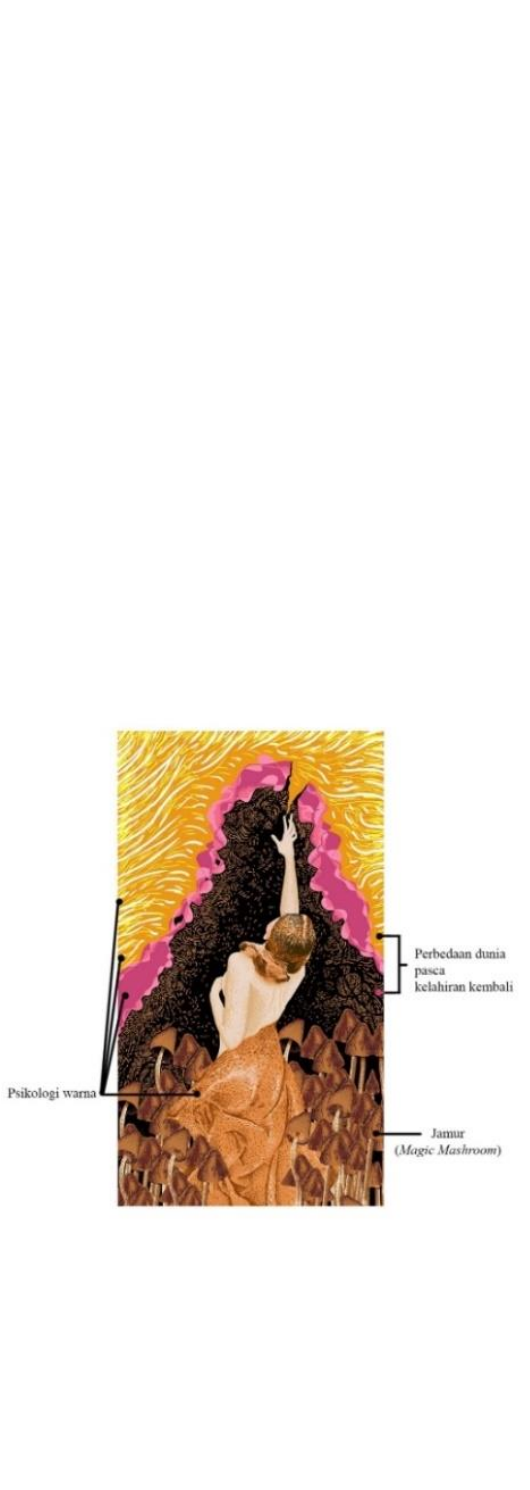 & $\begin{array}{l}\text { Sketch } 2 \text { shows a woman trying to get } \\
\text { out of a container filled with } \\
\text { mushrooms. The fungus which is } \\
\text { interpreted as a drug binds the woman. } \\
\text { The black color means the negative } \\
\text { world that the woman is experiencing. } \\
\text { A piece of dark orange cloth that half } \\
\text { holding the woman is interpreted as a } \\
\text { drug force that previously bound her } \\
\text { with self confidence and temporary } \\
\text { joy. The magenta and pink colors on } \\
\text { the border are interpreted as something } \\
\text { strong and difficult to get through. But } \\
\text { this woman is tougher than anyone } \\
\text { thought, she is able to break the drug } \\
\text { bonds and break the boundaries to } \\
\text { enter a new, brighter world. Slowly, } \\
\text { the woman is able to break free from } \\
\text { the drug bond and will come out } \\
\text { beyond that limit without a piece of } \\
\text { cloth (the drug that had previously tied } \\
\text { her) like a baby born into the world } \\
\text { without clothes. The bright orange, } \\
\text { yellow and white colors of the new } \\
\text { world symbolize the happiness that a } \\
\text { woman will feel when she succeeds } \\
\text { crossing the barrier. }\end{array}$ \\
\hline 3. & 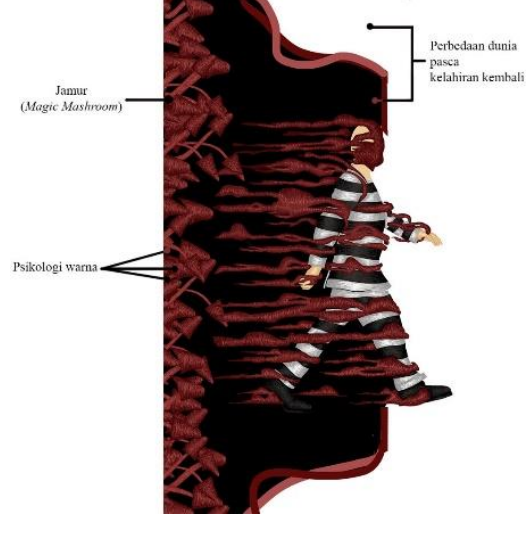 & $\begin{array}{l}\text { The red color of the mushrooms and } \\
\text { the barrier means that the drug- } \\
\text { inflicted power is so great in binding a } \\
\text { person. This bond includes the } \\
\text { labeling by the community for } \\
\text { someone who has ever consumed } \\
\text { drugs. This person has even felt the } \\
\text { jail so that many groups give a bad } \\
\text { identity to him. This identity is shown } \\
\text { by the prisoner's uniform that is still }\end{array}$ \\
\hline
\end{tabular}




\section{Artistic}

\begin{tabular}{|c|c|c|}
\hline & & $\begin{array}{l}\text { attached to his body, meaning that the } \\
\text { labeling of his past is still attached } \\
\text { even when he has tried to be better. } \\
\text { His past path still sticks in people's } \\
\text { memories and creates a bad } \\
\text { impression. However, this person is so } \\
\text { tough that he is able to cross the } \\
\text { barrier even though the community } \\
\text { still does labeling. He is still walking } \\
\text { out of the arena of negativity into a } \\
\text { better path. }\end{array}$ \\
\hline 4. & 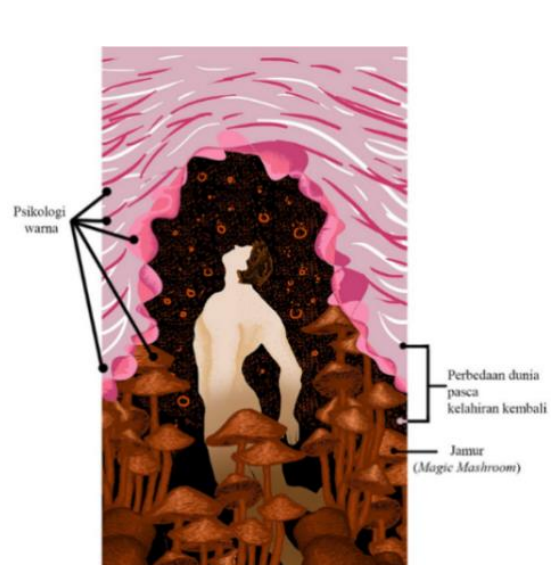 & $\begin{array}{l}\text { Someone tries to get out of the } \\
\text { negative world containing mushrooms } \\
\text { which means drugs. There is a } \\
\text { magenta and pink border which means } \\
\text { strong. Similar to the world he is going } \\
\text { to, the color pink is used to color the } \\
\text { world beyond the barrier, the positive } \\
\text { world. The pink color in a positive } \\
\text { world combined with white means to } \\
\text { be better. }\end{array}$ \\
\hline 5. & 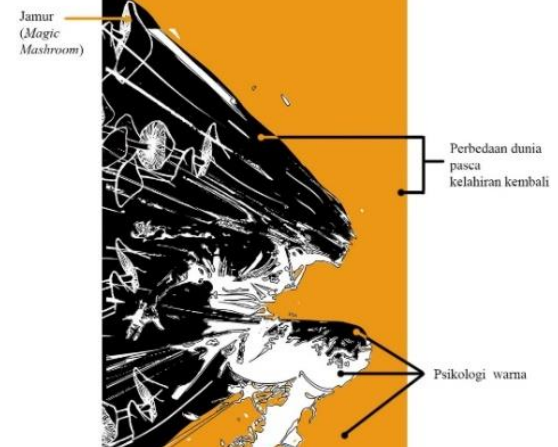 & $\begin{array}{l}\text { Sketch } 5 \text { uses black which means } \\
\text { strong in negative form to draw } \\
\text { someone back into the negative place. } \\
\text { Someone is trying to get out. The part } \\
\text { of the leg that has succeeded in } \\
\text { coming out is colored in white to } \\
\text { interpret the success of someone } \\
\text { getting out of the world of drugs }\end{array}$ \\
\hline
\end{tabular}

The third stage is visualization. After making a sketch, then a sketch selection is carried out and choose the 2 best designs to be turned into a work. 
Table 3. Design and artwork

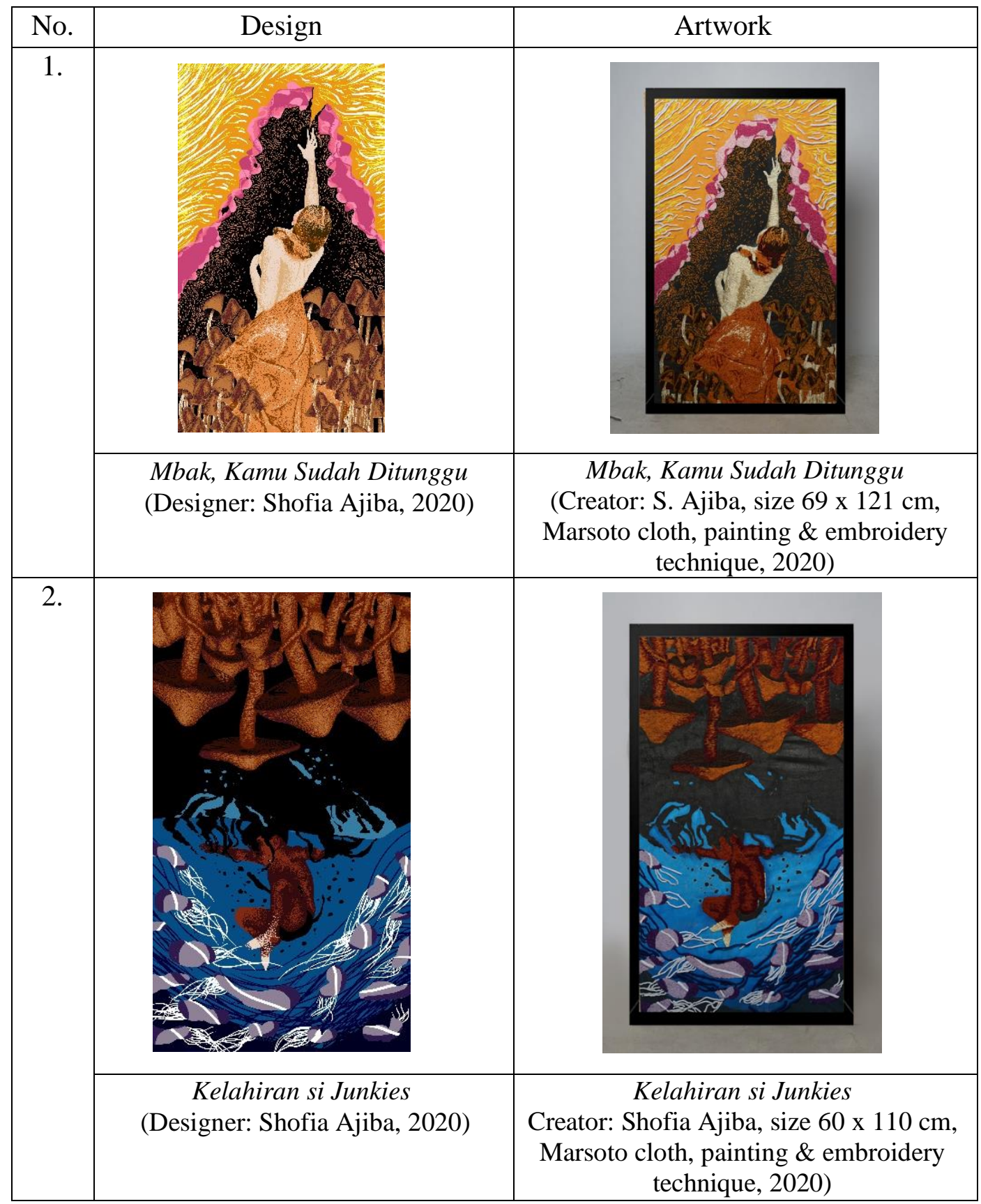

\subsection{Description of Art Work}

\subsubsection{Description of the Art Work entitled "Si Mbak, Udah Ditunggu Dirumah"}

The idea for this work came from a co-author who had the most difficult time in his life, namely being a drug abusers. This work presents the visual differences 


\section{Artistic}

between the two worlds in a woman (called Si Mbak). The first world is the world of drugs that she had experienced before and the new world after she left the world of drugs with the help of medical rehab and family support. The hardships of life in a rehabilitation center had made Si Mbak to give up on going through it. However, the message from the mother, who is a single parent, after her divorce from her husband, apparently strengthened her (Si Mbak). The message said, " Si Mbak, don't go home yet if you haven't healed yet, mother and your siblings can wait for you to arrive anytime ". Si Mbak left a message through this work to never forget how a person was when he was first born, namely in a holy condition. This is always used as motivation to stop any actions that are reconnected with drugs. Si Mbak also said that no one is holy after setting foot on earth, but humans are given the intellect to improve themselves to be better than before.

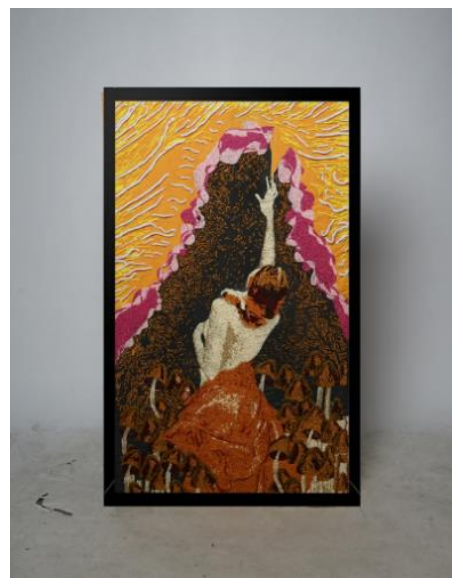

Figure 1. Si Mbak, Kamu Sudah Ditunggu (Creator : Shofia Ajiba, size $69 \times 121 \mathrm{~cm}$, Marsoto cloth, painting \& embroidery technique, 2020)

The difference in the world of Si Mbak before and after being released from drug bondage is very clearly illustrated. The black color means the darkness of her world when she was living with drugs, while the bright yellow means that it is as bright as her life now. The fungus that is tugging on the body of Si Mbak symbolizes the strength of the drugs in influencing the Si Mbak to continue with them. The cloth with the color of a fungus coiled around the Si Mbak's body, depicting her previous life covered in drugs. However, the lady is a strong person 
so that she is able to break the barrier between the positive and negative worlds which are depicted in pink lines with the ends starting to crack. Above the line, there are white tones which means clean, yellow which means freedom to be happy which indicates the success of Si Mbak on her graduation against the past.

\subsubsection{Description of the Art Work Entitled "Kelahiran si Junkies"}

This work shows a boy who has fallen into the water. It interprets the water birth method to mean a person's birth. Black water means the past of Si Junkies (drug addict) which is shown by the presence of mushrooms which means drugs. The mushroom that appears on it describes as if a living creature which is able to attract someone into its world.

Based on an idea from the data presented earlier, the age of drug users in Indonesia is 10-59 years old and the most users are teenagers. This fact is used as a source of ideas to describe objects in the visual work. The picture of the boy interpreted the ages of children to adolescents who were most vulnerable to falling into drugs. This work depicts a boy who manages to get out of the world of drugs which is visualized in dark colors.

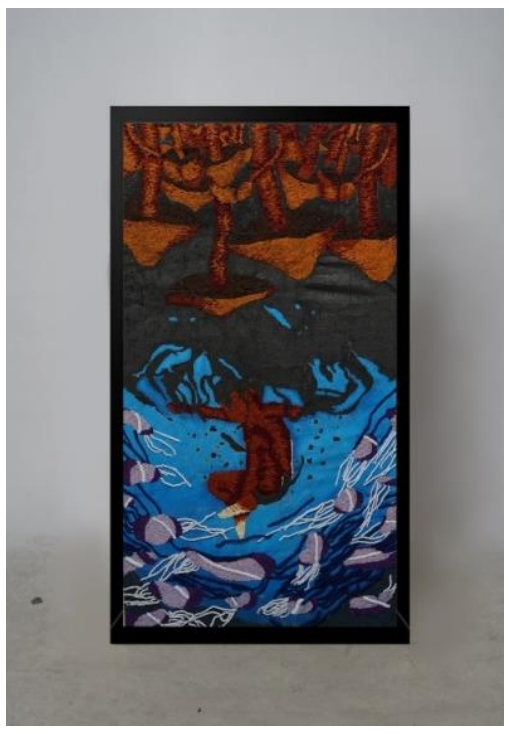

Figure 2. Kelahiran Junkie

(Creator : Shofia Ajiba, size 60 x $110 \mathrm{~cm}$, Marsoto cloth, painting \& embroidery technique, 2020) 
This creation also uses jellyfish which is defined as an influential subject in the process of one's birth to a better world, namely family and friends. Jellyfish were chosen to symbolize those who are able to help Si Junkies get out of drugs, because jellyfish are strong animals that are able to influence other creatures with their poison. Even jellyfish are one of the most poisonous animals in the world. The author does not focus on the poison (nature) of jellyfish which has a negative impact, but the author looks at jellyfish poison that affects its enemies. Like jellyfish, the surrounding environment such as family and friends can influence Si Junkies, because of the strong influence such as the effect of jellyfish poison.

The color of dark blue means the various strengths derived from the subjects around him in the form of support, love, and enthusiasm or spirit to become a better person. This work is expected to be able to touch a person's sense of learning from mistakes, then these mistakes are used as teachers so that in the future they are able to organize themselves to become better individuals.

\section{Conclusion}

From the creation of this textile artwork it can be concluded as follows: First, the creation of this textile artwork begins with exploration, an effort to collect layered data which is then poured into various sketch models. In this stage, the writer explores the visual of Panaeolus Cinetulus mushroom as a narcotic picture. This mushroom is one of the hallmarks ( characteristic ) of the creation of this work. Some sketches use the visual of the mushrooms as a point for interpreting the drug. Apart from mushrooms, contrasting colors with two different nuanses are used to emphasize the difference in the world from one another. In addition, the writer uses colors and symbols to translate the main purpose of this work, which is to convey a message. The mushroom symbol is defined as drugs, bright colors mean positive things, and dark colors mean negative things. However, the blue and black colors in the second work have undergone a process of consideration and are intended to portray harmony. 
Second, about the embodiment of textile works for aesthetic elements of the interior with the idea of birth. The two selected sketches were then realized on Marsoto cloth with sizes $121 \times 69 \mathrm{~cm}$ (work 1) and 110 × $60 \mathrm{~cm}$ (work 2). Marsoto was chosen because it is strong and has a heavier load than the thread that is the material for the work. The embroidery technique produces colors and lines that can be controlled. Apart from that, it also reminds us that all targets definitely require the sacrifice of time, so being patient, painstaking and being consistent is the best key to be able to produce details of the work that match expectations. Textile work can be used to touch someone's emotions to learn from mistakes, so they can become a better person.

\section{References}

Gustami, S. P. (2001). Proses Penciptaan Seni Kriya: Untaian Metodologis. Yogyakarta: Program Pascasarjana.

Prastiwi, E. Y. B., \& Listyaningsih. (2017). Motivasi Remaja dalam Mengikuti Rehabilitasi. Kajian Moral dan Kewarganegaraan, 5(2), 223-237. 